\author{
Justyna STECKO ${ }^{1}$
}

\title{
SUBJECTIVITY OF ANIMALS AND THEIR MORAL STATUS - HISTORICAL ASPECT
}

\begin{abstract}
A man as a conscious and rational being tries to define his place in the universe, himself in relation to the cosmos, absolute, logos and nature. Nowadays, the issue of our relations with animals is becoming particularly important. Historian Dominick LaCapra even stated that the 21 st century would be the age of animals ${ }^{2}$. A man uses animals in different ways: he eats their meat, apparels in their skin, uses them as a train force, plays with them at a cost in the circus and experiments in laboratories. It has been this way for centuries, but what seems crucial is that for some time the farms have become massive laboratories far too saturated with the suffering of animals, and the man, despite constant development, has changed little in his relation to animals. The aim of the paper is a brief description of the historical aspects of this phenomenon based on the views of philosophers over the past two thousand years. The analysis begins with the views of ancient philosophers such as Anaxagoras, Pythagoras and Aristotle, through the key concepts of medieval philosophers, first and foremost St. Augustine and Saint Thomas to modern times where attention was drawn to thinkers such as: Leonardo da Vinci, Michel Montaigne, Rene Descartes, Baruch Spinoza, La Mettrie, John Locke, Gottfried Wilhelm Leibniz, Jean Jacques Rousseau, Immanuel Kant, David Hume, Artur Schopenhauer or Jeremy Bentham. The considerations are concluded with a brief summary in the form of Darwin's concept.
\end{abstract}

Keywords: ethics, animals, moral status, history of philosophy, cruelty.

\section{INTRODUCTION}

Animals are used in the 21st century for various purposes. As we read in the literature there are different categories of animals, and in this place doubts may arise not only of the semantic nature. In this typology one can find the category of productive animals that are kept, bred or fished from nature for the purpose of their use, i.e. mainly for economic benefits ${ }^{3}$. In the further part of the paper one can find the terms "meat and fatty-meat productive livestock", which in my opinion clearly indicate the reification of these beings. In addition to the slaughter and consumption issues, which will still include the problem of slaughter, transport of animals or broadly understood breeding conditions, there are also issues of using animals for laboratory tasks, for the entertainment industry, or controversial

\footnotetext{
${ }^{1}$ Dr Justyna Stecko, adiunkt w Katedrze Nauk Humanistycznych, Politechnika Rzeszowska im. Ignacego Łukasiewicza, ul. Podkarpacka 1, 35-082 Rzeszów; e-mail: jstecko@prz.edu.pl. Justyna Stecko, PhD, Rzeszow University of Technology, them. Ignacy Lukasiewicz, Faculty of Management, Department of Humanities, Podkarpacka 1,35-082 Rzeszow; e-mail: jstecko@ prz. edu.pl.

${ }^{2}$ M. Bekoff, J. Pierce, Dzika sprawiedliwość, Kraków 2018, p. 8.

${ }^{3}$ Encyklopedia PWN.
} 
treatment of pets and extremely controversial understood by many as hunting entertainment. There are many problems in this field, hence the question arises when the human-animal relationship began to be considered at all and whether modern animal treatment has its roots in ancient times.

\section{A HUMAN BEING AND ANIMALS}

Stories of cruelty to animals go back thousands of years. The Romans already staged on the amphitheater or circus arena "hunting" where - just for the delight of the audience one day thousands of wild animals died ${ }^{4}$. Transported to Rome, also these exotic animals were to serve as a variety of games. Quintus Scewola arranged the first amphitheatrical "hunts" with the participation of lions, and animal fights and against the gladiators became a permanent element of the games. Only on one day of the Olympics organized by Titus in the year 80 on the occasion of the opening of the Colosseum five thousand animals were exhibited on the arena ${ }^{5}$. Stories about conquistadors who made bloody floods were not unknown to literature. "A seaman was seen who, in a frenzy of jubilation, killed an unhappy female seal; she cried like a woman, and how many times the bloodied mouth opened, he

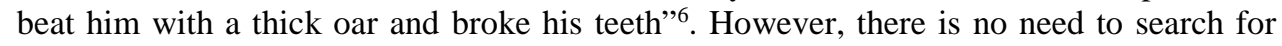
bloody tales in only ancient times.

From 1934 in the American city of Hegins, Pennsylvania, on Labor Day shooting to live animals took place. It was finally was banned only in 1998. Five thousand pigeons were released during the event only to become a living shield. Most of the shot birds were wounded and did not die on the spot, but children were responsible for "catching" them. "At the end of each round, the children collected the wounded birds and killed them - stepping on them, tearing their heads off, hitting them against the walls of the barrels or throwing them to them, to be strangled by other dying or already dead birds"7.

Noteworthy is the well-known Italian film "Mondo cane" (Dog's world) which not only focuses on hunting for young seals and whales but also on the way we treat animals before they become food. The spectator "visits" a Chinese restaurant where a consumer can choose a particular dog that will be served on his plate.

Another modern problem are experiments on animals. Hundreds of millions of different types and species die in laboratories all around the world. They are usually used for testing drugs, cosmetics, pesticides or toilet products. "Almost $70 \%$ of animal tests are carried out without anesthesia so that the results are $100 \%$ reliable. $32 \%$ of experiments last longer than a month, $66 \%$ of experiments cause unbearable animals to withstand pain" ${ }^{\text {. }}$.

Another aspect of the human-animal relationship is the issue of industrial breeding, slaughter or transport of these beings. Farm animals often have such tight stands that they cannot turn or lie down. Slaughter animals from the time of purchase until slaughter are not

\footnotetext{
${ }^{4}$ http://www.miesiecznik.znak.com.pl/6372008michal-bardelbestiarium-pliniusza-czyli-o-relacjiludzi-i-zwierzat-w-starozytnym-rzymie/ [13.12.2017].

5 Ibidem.

${ }^{6}$ For more see: J. Stecko, Homo crudelis - koncepcja natury ludzkiej Mariana Zdziechowskiego w zderzeniu z czasami wspótczesnymi, Zeszyty Naukowe Politechniki Rzeszowskiej, seria: „Ekonomia i Nauki Humanistyczne" No. 1/2011, p. 237-245.

7 D. DeGrazia, Prawa zwierząt. Bardzo krótkie wprowadzenie, Kraków 2014, p. 26.

${ }^{8}$ https://czarnaowca.org/zwierzeta/co-sie-dzieje-ze-zwierzetami/eksperymenty-na-zwierzetach/
} 
fed, often not banned, and when unloaded, beaten and maimed. Chickens for roasting on a spit are grown in very cramped and dark rooms and during their lifetime their beaks are cut off because they are pecking each other outrageously9. Paul McCartney said that "if the slaughterhouses had glass walls, everyone would be a vegetarian" ${ }^{10}$. Stories about how doubtful the morality of a man towards animals can be multiplied without end. However, the more important question is why is this so? Who is responsible for the fact that in the twentieth and twenty-first century, an animal is more a thing than a "no-show"? Is the consequence to be found in historical relations and the way these beings are treated?

\section{A HISTORICAL LOOK AT THE RELATIONSHIPS OF THE ANIMAL AND HUMAN WORLD ${ }^{11}$}

Animal problems appeared in the texts of ancient thinkers and were not unanimous concepts. Ancient philosophers perceived animals differently, beginning with the idea of panaxychism of Anaxagoras where animals arose from a special seed that fell from the sky (ether), through the concept of Pythagoreans who believe in metempsychosis, or the possibility of rebirth of the human soul in the body of other beings, e.g. animals, and so and great respect for them, up to the concept of Plutarch, who not only devoted several treaties to the issue of animals but also argued in them that animals show intelligence even higher than humans. Interestingly, the treatise On the cleverness of animals goes a step further and attributes to animals even certain features of moral virtues ${ }^{12}$. An even more bold hypothesis is the concept of cynics, including Diogenes of Synopa, who even recognized animals as beings superior to a man ${ }^{13}$. However, the most typical of this period and later times is the Aristotelian concept which saw only in animals the subject of a being serving a man. On the one hand he defined the human being as an animal, albeit a social and rational (zoon politicon), and did not deny souls who are responsible for feeling and following the impulses in these creatures, but each time it was in the concept much lower down in hierarchy and worse salaried.

The Middle Ages and conceptions of subsequent saints were also not homogeneous, and in the vast majority of them gradually became more and more severe. St. Augustine referred to animals as "creatures that are devoid of reason, flying, floating, walking and crawling, since they are not joined by the possession of reason" 14 . A similar view was made by Saint Thomas who dedicated a separate article to the animal world in the De Veritate study and a series of occasional remarks in the Theological Sum ${ }^{15}$. All non-human creatures, i.e. animals or plants, are only instruments needed to meet human needs. Because of the lack of reason, as St. Thomas said, they are not subject to moral judgments or punishments. It is not important how a man deals with animals, for God has subject all earthly things to the

\footnotetext{
9 It is worth paying attention to the organization of "Open Cages" and the growing number of voices in discussions in Poland on animal welfare, including texts by Dorota Probucka, Andrzej Elżanowski and many others.

${ }^{10}$ P. McCartney, S. McCartney, M. McCartney, Poniedziałki bez mięs, Poznań 2012.

11 Due to the volume of the text, I deliberately omit the religious aspect.

12 T. Ślipko, Bioetyka, Kraków 2009, p. 55.

$13 \mathrm{http}: / /$ niechcianeizapomniane.org/filozofia-praw-zwierzat/ [23.12.2017].

14 Św. Augustyn, O Państwie bożym, Warszawa 2010, Vol. II, p. 231.

15 T. Ślipko, Bioetyka..., p. 56.
} 
possession of $\operatorname{man}^{16}$. The doctrines of Saint Albert and Saint Bonaventure are in the same framework ${ }^{17}$. One of the few thinkers in this period who dared to reduce the distance between the world of animals and man was St. Francis of Assisi. "Our primary duty towards our younger brothers is not to hurt them, but it will not stop there. We have a more important mission - to help them, whenever they need it" ${ }^{\prime 18}$. However, his views, though full of love for all living beings, changed little in the views of his living.

Renaissance humanism did not destroy the medieval barriers dividing the world of people and animals. In the Renaissance ideas such as human dignity, its central place in the world and the uniqueness of its nature were raised and they were contrasted with the nature of other, lower species. It is true that one of the greatest minds of this time Leonardo da Vinci, a vegetarian who utters the words: "The time will come when people like me will look at the animal killer as they look at the murderer of people" did not change much in the way of thinking about non-human beings ${ }^{19}$.

It seems, however, that Michel de Montaigne had the most open views among the philosophers of this period for equality among all living creatures. In his opinion a man, despite his predispositions, should not feel distinguished from the group of animals because he does not belong to any higher species. On the one hand, he criticizes religious comparisons concerning the creation of a man in the likeness of God, on the other hand, he indicates that in comparisons we are closer to animals. Referring directly to the Bible he points to the typically wrong human beliefs: "A man who is nothing if he is thought to be something, deceives himself" 20 . Montaigne has clearly condemned cruelty to animals, not yet, for fear of being transferred to humans, but for the very animals that have the same right to live as humans.

"As far as I am concerned, I have never been able to look without anger at how persecuting and killing an innocent and defenseless animal that does no harm to us" 21 . However, the philosopher's way of thinking was not popular. The ideas that definitely deepened the gap between the world of animals and people were the views of Spinoza, and the thought of Descartes made a particular evil. The first of them admitted to the animals the right to feel, but at the same time he argued that they were different from human feelings, so it was allowed to use them at will. According to Spinoza, everything that exists should be designed to meet human needs. A man can take a full advantage of the natural world and "the law prohibiting the killing of animals is based more on vain superstition and on a woman of mercy than on common sense ${ }^{22}$. It seems, however, that the Cartesian theory of res extensa and res cogitans did the most evil. The consequences of the Cartesian way of thinking are visible until today. According to Descartes, a man is a "thing of thought" while the rest of the beings are only "a stretch thing", and the only element that "makes us human and different from animals" 23 is reason. In other words, trivializing somewhat, the difference between a coffee machine and, for example, a dog is only to a degree of specialization,

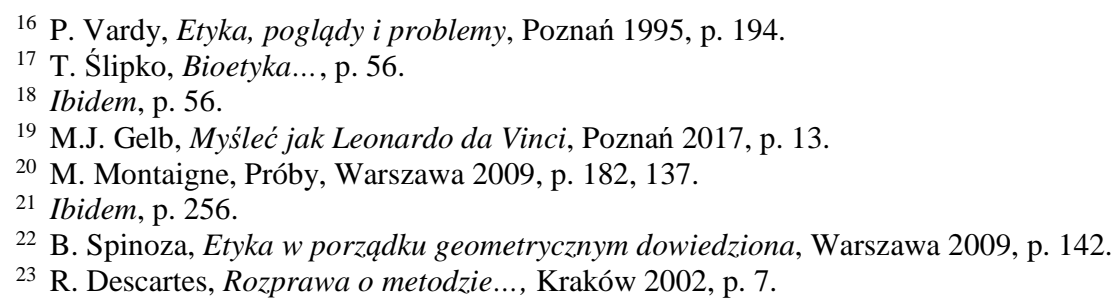


although at this point the most likely problem would be the indication of the hierarchy. Animals are only machines that have no communication skills, do not know suffering. "My views are not so cruel to animals as comfortable for people - at least for those who do not believe in Pythagoras' superstitions - they free them from the accusation of crime when they eat or kill animals"24.

The aftermath of the Cartesian concept were numerous experiments on live animals. In the name of science, without remorse, the animals were mutilated, cut and, consequently, cruelly killed. At this point, a great example of an experiment by a Russian scientist who described Polish thinker Marian Zdziechowski seems to be: "Professor and rector of the medical school in St. Petersburg, Paszutin who said [...] how he decided to experimentally explore the dog's soul. For this purpose, he bought a dog, he tamed it; the dog tied to him and licked his hands. Then Paszutin poured a booze over him; the skin fell from the dog, but he licked the hands of his torturer. For the second time Paszutin poured a splash; despite the torment, the dog did not stop licking the hand of the »priest of science «; once more the dog was poured with a boil; he did not endure and breathed its last" ${ }^{\prime 25}$. La Mettrie entered the discourse with Descartes. He pointed out that not only animal organisms worked like machines but also human ones exhibited exactly the same principles. A man - machine is a revolutionary and courageous concept not only indicating similarities with the natural world but above all indicating some regularities that are worth investigating in the context of human sciences.

An extremely interesting concept was the thought of Johne Locke who drew attention to consciousness, but not only in the concept of a man but also animals. He noticed many similarities in the consciousness of animals and people: from such qualities as memory, an ability to distinguish and express emotions with the voice. However, the concept of reason he left as an element differentiating the world of animals and people ${ }^{26}$. We can also see Leibniz's views on the mental abilities of animals. However, the essential difference that only people are able to understand morality and the thinker's ability to think abstract ${ }^{27}$. Another of the breakthrough thinkers of this era who recognized that animals had the right to be treated well by people was J.J. Rousseau. On the one hand, he pointed to human superiority because of freedom and consciousness in making decisions as opposed to animal instinctive behaviors, and on the other hand indicated the need for respect for beings - in his opinion, lower beings.

These concepts were, unfortunately, opposed by Immanuel Kant, for whom only a man can be the subject of morality. Only members who are capable of surrendering their desires to the control and power of practical reason may belong to the community of "moral subjects". In addition, the maxim referring to a man as an end in itself and "humanity as in itself, as in every always at the same time as a goal and never as a middle" 28 indicates the decisive superiority of human beings over the rest of the animal world. Animals not having moral subjectivity, being unable to make laws, seem to remain in the world of "things" and only play an instrumental role for those who are "goals in themselves". This does not mean

\footnotetext{
${ }^{24}$ P. Singer, Wyzwolenie zwierzat, Warszawa 2004, p. 271-273.

${ }_{25}$ M. Zdziechowski, O okrucieństwie, Kraków 1993, p. 58-59.

26 J. Locke, Rozważania dotyczace rozumu ludzkiego, Warszawa 1955, p. 490.

${ }^{27}$ Ibidem, p. 490.

${ }^{28}$ I. Kant, Uzasadnienie metafizyki moralności, Warszawa 1953, p. 65, 66, 68-71.
} 
that he was an advocate of unnecessary suffering, but his theory was an obstacle in the fight for better treatment of animals.

If we are looking for a philosophical concept that could help in the discussion about animal welfare, it is necessary to recall the concept of David Hume. In his opinion, "no truth seems more obvious to me than the fact that animals are endowed with thought and reason as well as human" ${ }^{29}$. He regarded feelings about animals and nature as an important element of our culture, while indifference and worse cruelty seemed to humiliate people ${ }^{30}$. An important defense of animals is the concept of Artur Schopenhauer, who directly calls "people devils in this land and animals tormented by their souls" 31 . He paid particular attention to consciousness. "This distinctive feature, which means the right word" reason "is that a man is capable - not like an animal - only for imaginary comprehension of the alien world that he can abstract from it general concepts, which means words for this purpose, to establish and maintain in their sensual consciousness, creating the next innumerable combinations thereof"32.

It seems, however, that Jeremy Bentham had the biggest influence on the animal rights discussions. In his opinion, "one should ask not whether animals can reason or whether they can speak, but whether they can suffer"33. A man, when he wants to show his greatness, has emphasized for centuries that he surpasses animals with reason and communication skills instead of paying attention to what unites us. No matter what we are different, we are all capable of suffering. It was Bentham who, as one of the first, categorically opposed the tyrant of a man: "May the day come when the rest of the living creatures received the rights that only tyrant's hand could take away from them ... Let the day come when everyone recognizes that the number of legs, skininess or the ending of the sacred axis is also not convincing arguments for letting a feeling subject be let loose for torment. Because of what can be set an impassable boundary? It would be because of the ability to reason or perhaps the gift of speech? However, an adult horse or dog is incomparably a more intelligible and capable animal to communicate with a day or a week - old, or even a month of life child" 34 . Less than 30 years after the death of Jeremy Betham, the theory of Charles Darwin evolution appeared, and whatever its scientific value gave rise to a new understanding of the relationship between a man and animals. Darwin argued that there was no fundamental and significant intellectual difference between human and higher mammals. It is true that these theories arouse many controversies and in some cases even violent opposition, but they gave rise to the idea of universal brotherhood. Darwin called for the humane treatment of animals, he pointed out that only such behavior is fitting to human dignity. These views have largely changed the view of animal-human relationships.

29 D. Hume, Traktat o naturze ludzkiej, Warszawa 1963, p. 231.

${ }^{30}$ Cf.U. Zarosa, Status moralny zwierzat, Warszawa 2016, p. 25 and 27.

${ }^{31}$ For more see: J. Stecko, Homo crudelis...

32 A. Schopenhauer, $O$ wolności ludzkiej woli, Kraków 2004, p. 44; A. Schopenhauer, O podstawie moralności, Warszawa 2009, s. 383.

33 J. Bentham, Wprowadzenie do zasad moralności i prawodawstwa, Warszawa 1958, p. 419-420, following P. Singer, Zwierzęta i ludzie jako istoty równe, Etyka No. 18, 1980, p. 51.

${ }^{34}$ Ibidem. 


\section{CONCLUSION}

The turn of the 19th and 20th centuries, largely due to Darwinism, brought a new quality of ethical and ecological philosophy. The 20th and 21st centuries are also very rich in discussions and views about human and animal relations, however, due to the format and volume, this is material for an independent text. One of the first conclusions which appears after analyzing the views of selected philosophers is the fact of the lack of unanimity regarding the assessment of the intellectual possibilities of animals and their ability to feel and, consequently, to experience suffering. Many of them refused to be able to feel at all, and at most pain was treated as one of the stimuli. The result of such views were numerous experiments on living organisms. And one of the key conclusions that in most views a man felt the reeve and master of other natural beings. The consequences of this way of thinking are noticeable to this day.

\section{REFERENCES}

1. Bekoff M., Pierce J., Dzika sprawiedliwość, Kraków 2018.

2. Bentham J., Wprowadzenie do zasad moralności i prawodawstwa, Warszawa 1958.

3. DeGrazia D., Prawa zwierząt. Bardzo krótkie wprowadzenie, Kraków 2014.

4. Descartes R., Rozprawa o metodzie..., Kraków 2002.

5. Gelb M.J., Myśleć jak Leonardo da Vinci, Poznań 2017.

6. Hume D., Traktat o naturze ludzkiej, Warszawa 1963.

7. Kant I., Uzasadnienie metafizyki moralności, Warszawa 1953.

8. Leibniz G.W., Nowe rozważania dotyczace rozumu ludzkiego, Warszawa 1955.

9. Locke J., Rozważania dotyczace rozumu ludzkiego, Warszawa 1955.

10. McCartney P., McCartney S., McCartney M., Poniedziałki bez mięs, Poznań 2012.

11. Montaigne M., Próby, Warszawa 2009.

12. Schopenhauer A., O wolności ludzkiej woli, Kraków 2004.

13. Schopenhauer A., O podstawie moralności, Warszawa 2009.

14. Singer P., Wyzwolenie zwierzat, PWN, Warszawa 2004.

15. Singer P., Zwierzęta i ludzie jako istoty równe, „Etyka” 1980, nr 18.

16. Spinoza B., Traktaty. Etyka, Warszawa 2009.

17. Stecko J., Homo crudelis - koncepcja natury ludzkiej Mariana Zdziechowskiego w zderzeniu z czasami wspótczesnymi, Zeszyty Naukowe Politechniki Rzeszowskiej, seria: „Ekonomia i Nauki Humanistyczne" nr 1/2011.

18. Ślipko T., Bioetyka, Kraków 2009.

19. Św. Augustyn, Państwo Boże, Warszawa 2010.

20. Vardy P., Etyka, poglądy i problemy, Zysk i spółka, Poznań 1995.

21. Zarosa U., Status moralny zwierząt, Warszawa 2016.

22. Zdziechowski M., O okrucieństwie, Kraków 1993. 


\section{INTERNET SOURCES}

1. http://niechcianeizapomniane.org/filozofia-praw-zwierzat/ (23.12.2017).

2. http://www.miesiecznik.znak.com.pl/6372008michal-bardelbestiarium-pliniusza-czyli-orelacji-ludzi-i-zwierzat-w-starozytnym-rzymie/ (13.12.2017).

3. https://czarnaowca.org/zwierzeta/co-sie-dzieje-ze-zwierzetami/eksperymenty-na-zwierze$\operatorname{tach} /(23.12 .2017)$.

4. https://swietostworzenia.pl/czytelnia/16-ekologia-franciszkanska/122-ekologiczny-dekalogsw-franciszka-z-asyzu (23.12.2017).

\section{PODMIOTOWOŚĆ ZWIERZĄT I ICH STATUS MORALNY - ASPEKT HISTORYCZNY}

Człowiek jako istota świadoma i rozumna stara się określić swoje miejsce we wszechświecie, siebie wobec kosmosu, absolutu, logosu i przyrody. Współcześnie zagadnienie naszych relacji ze zwierzętami staje szczególnie ważne. Historyk Dominick LaCapra stwierdził nawet, że XXI wiek będzie wiekiem zwierzą ${ }^{35}$. Człowiek wykorzystuje zwierzęta na różne sposoby: zjada ich mięso, odziewa się w ich skórę, używa jako siły pociągowej, bawi się ich kosztem w cyrku oraz eksperymentuje w laboratoriach. Tak było od wieków, jednak to co wydaje się kluczowe to to, że od pewnego czasu hodowle stały się masowe, laboratoria zdecydowanie zbyt przesycone cierpieniem zwierząt a człowiek, mimo ciągłego rozwoju, niewiele zmienił w swoim stosunku do zwierząt. Celem artykułu jest krótka charakterystyka historycznych aspektów tego zjawiska w oparciu o poglądy filozofów na przestrzeni pond dwóch tysięcy lat. Analiza rozpoczyna się poglądami starożytnych filozofów takich jak Anaksagoras, Pitagoras czy Arystoteles, poprzez kluczowe koncepcje filozofów średniowiecznych przede wszystkim św. Augustyna i św. Tomasza aż po czasy nowożytne, w których zwrócono uwagę na myślicieli takich jak: Leonardo da Vinci, Michel Montaigne, Rene Descartes, Baruch Spinoza, La Mettrie, John Locke, Gottfried Wilhelm Leibniz, Jean Jacques Rousseau, Immanuel Kant, David Hume, Artur Schopenhauer czy Jeremy Bentham. Rozważania kończy krótkie podsumowanie w postaci koncepcji Darwina.

Słowa kluczowe: etyka, zwierzęta, status moralny, historia filozofii, okrucieństwo.

DOI: $10.7862 /$ rz.2018.hss.58

Przestano do redakcji: styczeń $2018 \mathrm{r}$.

Przyjęto do druku: wrzesień 2018 r.

\footnotetext{
${ }^{35}$ M. Bekoff, J. Pierce, Dzika sprawiedliwość, Kraków 2018, s. 8.
} 